\title{
Strategi Pemerintah Dalam Menyetarakan Hubungan Tauke Di Desa Malang Rapat Kabupaten Bintan
}

\author{
Yennita $^{1)}$, Rumzi Samin ${ }^{2)}$, Imam Yudhi Prastya ${ }^{3)}$ \\ ${ }^{1,3}$ Program Studi Ilmu Administrasi Negara, ${ }^{2}$ Program Magister Administrasi Publik \\ Falkultas Ilmu Sosial Dan Ilmu Politik Universitas Maritim Raja Ali Haji \\ yennita82@yahoo.com,rumzisamin@umrah.ac.id, yudhiimam@umrah.ac.id
}

\begin{abstract}
ABSTRAK
Penelitian ini bertujuan untuk mengevaluasi starategi pemerintah untuk mengatasi hubungan patron klien diDesa MalangRapat. Penelitian ini menggunakan metode deskriptif dengan pendekatan kualitatif. Teknik analisis data dilakukan dengan cara pengumpulan data, penyajian data, penarikan kesimpulan dan verifikasi data. Hasil penelitian evaluasi strategi pemerintah untuk mengatasi hubungan patron klien diDesa MalangRapat adalah: Pertama, Efektivitas, bantuan yang disalurkan sangat memberikan mamfaat bagi nelayan karena bisa meningkatkan hasil tangkapannya dan bisa membantu keuangan keluarga. Kedua Efisiensi,mengenai anggaran bantuan. Pemerintah memiliki anggaran dan berwewenang untuk memenuhi kebutuhan nelayan. Ketiga, Kecukupan, masyarakat sangat terbantu dengan adanya bantuan, tetapi kurangnya dalam Sumber Daya Manusia (SDM). Keempat Perataan, penyaluran bantuan ini belum bisa dikatakan efektif,karena masih ada nelayan yang belum menerima bantuan. Keenam, Responsivitas, respon masyarakat sangat positif adanya bantuan dan mendukung dengan baik tujuan bantuan tersebut. Keenam, Ketetapan, program bantuan ini tepat untuk dijalankan karena tujuan dari program ini sangat bernilai untuk pengetasan kemiskinan bagi masyarakat nelayan.
\end{abstract}

Kata Kunci: Evaluasi, Strategi, Patron Klien.

\section{Abstrak}

This study aims to evaluate the government's strategy to overcome the patron-client relationship in MalangRapat Village. This study uses a descriptive method with a qualitative approach. The data analysis technique was done by collecting data, presenting data, drawing conclusions and verifying data. The results of the research on evaluating the government's strategy to overcome the patron-client relationship in MalangRapat Village are: First, effectiveness, the assistance provided is very beneficial for fishermen because it can increase their catch and can help with family finances. Second Efficiency, regarding the aid budget. The government has the budget and has the authority to meet the needs of fishermen. Third, Adequacy, the community is greatly helped by the assistance, but lacks in Human Resources (HR). Fourth, the distribution of this assistance cannot be said to be effective, because there are still fishermen who have not received assistance. Sixth, responsiveness, the community's response is very positive and supports the purpose of the aid. Sixth, provision, this assistance program is appropriate to run because the purpose of this program is very valuable for poverty reduction for fishing communities

Keywords: Evaluation, Strategy, Client Patron 


\section{PENDAHULUAN}

Indonesia merupakan salah satu negara kepulauan terbesar yang memiliki laut sekitar $70 \%$, maka wajar kalau terdapat banyak aktifitas kehidupan penduduk indonesia berada di sekitar pantai sebagai nelayan. Masyarakat nelayan merupakan salah satu bagian masyarakat Indonesia yang hidup dengan mengelola potensi sumberdaya perikanan. Sebagai makhluk sosial manusia berintraksi dengan lingkungan sosial dan lingkungan alam. Hal ini disebabkan karena manusia dalam usahanya melangsungkan hidupnya selalu tergantung pada lingkungan, baik lingkungan sosial maupun lingkungan alam dimana pun berada. ketergantungan manusia terhadap lingkungan terwujud dalam bentuk intraksi sosial yang berlangsung dilingkungan tersebut.

Pada umumnya para nelayan masih mengalami keterbatasan teknologi penangkapan sehingga wilayah opersipun menadi terbatas hanya disekitar perairan pantai. Disamping itu ketergantungan terhadap musim sangat tinggi dan tidak setiap saat nelayan bisa melaut, terutama pada musim ombak yang berlangsungan lebih dari satu bulan. Akibatnya tidak ada hasil tangkapan yang bisa diperoleh. Kondisi ini jelas tidak menguntungkan nelayan karena secara riil rata-rata pendapatan per bulan menjadi kecil, dan pendapatan yang diperoleh pada saat musim ikan akan habis dikonsumsi pada saat peceklik. Rendahnya nilai tukar ikan, mahalnya harga-harga kebutuhan sehari-hari dan besarnya tanggungan keluarga juga merupakan faktor penyebab kemiskinan nelayan. Kemiskinan merupakan masalah yang bersifat kompleks dan multi dimensional, baik dilihat dari aspek kultural maupun aspek struktural. Ada empat masalah pokok yang menjadi penyebab dari kemiskinan, yaitu kurangnya kesempatan, rendahnya kemampuan, kurangnya jaminan dan keterbatasan hakhak sosial, ekonomi dan politik sehingga menyebabkan kerentanan, keter-purukan, dan ketidakberdayaan dalam segala bidang.

Tabel 1 Jumlah Penduduk Miskin 2017-2019

\begin{tabular}{|l|c|c|c|c|c|c|}
\hline \multirow{2}{*}{ Wilayah } & \multicolumn{6}{|c|}{ Jumlah penduduk miskin (ribu jiwa) } \\
\cline { 2 - 8 } & \multicolumn{2}{|c|}{2017} & \multicolumn{2}{c|}{2018} & \multicolumn{2}{c|}{2019} \\
\cline { 2 - 7 } & Maret & September & Maret & september & maret & september \\
\hline Kepulauan riau & 125.37 & 128.43 & 131.68 & 123.36 & 594059 & 602038 \\
\hline Karimun & 16.94 & - & 15.93 & - & 376853 & - \\
\hline Bintan & 9.37 & - & 10.42 & - & 384396 & - \\
\hline Natuna & 3.53 & - & 3.60 & - & 378573 & - \\
\hline Lingga & 12.35 & - & 12.13 & - & 429764 & - \\
\hline $\begin{array}{l}\text { Kepulauan } \\
\text { anambas }\end{array}$ & 2.84 & - & 2.90 & - & 382449 & - \\
\hline Batam & 61.16 & - & 67.41 & - & 686956 & - \\
\hline Tanjungpinang & 19.19 & - & 19.30 & - & 659170 & - \\
\hline
\end{tabular}

Sumber:Badan Pusat Statistik,2020

Kepulauan Riau merupakan wilayah yang kaya dengan sumber daya alam salah satunya laut, laut merupakan tempat dimana masyarakat yang tinggal dipesisir pantai yang mayoritasnya nelayan, Malang rapat merupakan salah satu desa yang berada di kabupaten bintan. Sebagian besar peduduk desa malang rapat berpencaharian sebagai nelayan. Hal ini dikarenakan lokasi desa malang rapat yang dekat dengan laut. Kondisi ini membuat penduduk berbondong-bondong untuk memanfaatkan hasil laut di desa Malang rapat. Namun, keadaan ini tidak membuat masyarakat terlepas dari lingkar kemiskinan. Secara keseluruhan keberadaan nelayan tradisional berada pada garis kemiskinan dan secara khusus 
nelayan tradisional di Desa Malang rapat. Strategi adaptasi yang dilakukan oleh nelayan di daerah tersebut dalam mengatasi kesulitan ekonomi dalam kehidupan sehari-hari adalah menjalin hubungan patron-klien.

Hubungan yang dimaksud adalah hubungan yang membentuk hubungan patron-klien. Menurut Scott seperti dikutip oleh Kusnadi (2000) dalam (Sufirudin, 2016) hubungan patron-klien merupakan kasus khusus hubungan antara dua orang yang sebagian besar melibatkan persahabatan instrumental, di mana seseorang yang kedudukan sosialnya lebih tinggi (patron) menggunakan pengaruh sumber daya yang dimilikinya untuk memberikan perlindungan atau keuntungan, atau kedua-duanya kepada orang yang memiliki status sosial yang lebih rendah (klien). Selanjutnya klien membalas pemberian tersebut dengan memberikan dukungan dan bantuan termasuk jasa-jasa pribadi kepada patron. Menurut Legg yang dikutip oleh Kusnadi (2000) dalam (Sufirudin, 2016), tujuan dari kedua belah pihak baik patron maupun klien menjalin hubungan patron-klien ini adalah memperoleh keuntungan berupa barang, jasa atau sumber daya lain yang tidak dapat diperoleh melalui cara lain atas pengorbanan yang telah meraka berikan. Menurut Hefni yang dikutip oleh (Sinaga, 2015) hubungan patron-klien ditandai dengan patron memberikan pekerjaan, perlindungan, infrastruktur dan berbagai manfaat lainnya kepada klien yang tidak berdaya dengan imbalan klien memberikan berbagai bentuk kesetiaan, pelayanan dan bahkan dukungan politik kepada patron. Dengan menjalani hubungan tersebut masyarakat nelayan sulit mendapatkan hasil ekonomi yang cukup, tetapi dengan menjalankan hubungan itu dengan tauke (patron) bisa menbantu untuk mengatasi ekonomi pada musim-musim yang tidak bisa melaut. Dengan hal tersebutlah nelayan terikat dengan tauke/juragan dan berkelanjutan.

Di Desa Malang Rapat kebanyakan pekerjanya adalah nelayan dari masa kemasa, pergulatan masyarakat nelayan melawan ketidak pastian kehidupan, khususnya bagi nelayaan penangkapaan ikan, penatian yang panjang untuk menuai kesejahteraan hidup yang lebih baik. Lebih dari itu, kemiskinan nelayan didesa malang rapat menjadi fenomena yang umum yang banyak terjadi. Dalam keadaan seperti ini, sebagian nelayan membutuhkan keadaan tauke yang memiliki modal yang besar, sehingga sering terjadi suatu hubungan (relasi) kerja sama nelayan dengan tauke. Salah satu terjadinya hubungan kerja sama antara tauke dan nelayan yaitu tauke bersedia memberi pinjaman kekurangan biaya untuk beropersi ke laut, dan boat untuk nelayan pakai ketika mencari ikan disitulah terhjadinya hubungan tersebut.

Didesa Malang Rapat juga tidak memiliki akses pasar yang untuk digunakan para nelayan untuk menjual hasil tangkapannya, sehingga nelayan disana terpaksa harus menjual hasil tangkapan ke tauke/juragan, dengan masalah tersebut nelayan sulit untuk mendapatkan hasil ekonomi yang diingin kan. Dari permasalahan nelayan tersebut tidak lepas dari pemerintah. pemerintah berusaha mengatasi hubungan patron klien yang ada didesa Malang Rapat dengan cara memberi bantuan seperti pompong, kelong, alat tangkap, dan lain-lain, namun bukan perkara mudah bagi pemerintah untuk mengatasi hubungan tersebut dikarenakan tauke-tauke disana lebih menguasai tempat. Pemerintah telah memberikan bantuan kepada masyarakat nelayan untuk mengatasi hubungan patron klien. Tetapi banyak terlihat masyarakat nelayan tidak bisa menggunakan bantuan tersebut sesuai kegunaanya dikarnakan ada nelayan yang kurang memahami dan ada nelayan yang memahami kegunaan alat tangkap yang diberikan pemerintah. Setiap nelayan pun memiliki 
tingkat kemampuan yang berbeda-beda dalam menggunakan alat tangkap yang diberikan pemerintahah, dengan keterbatasan kemampuan itu sehingga banyak alat tangkap yang di jual oleh nelayan yang tidak mengerti menggunakannya.

Eko Cahyono mengatakan didesa Malang Rapat selalu mengalir bantuan yang diberikan pemerintah, tetapi masyarakat mengakui yang diberikan bantuan itu hanya orangorang itu saja. Dan masalah lainnya, jenis bantuan yang diberikan tidak sesuai dengan yang diharapkan, dan pada akhirnya banyak yang dijual. Selama tidak melaut para nelayan lebih banyak menghabiskan waktu di rumah. Mereka tidak punya pilihan lain, karena satusatunya sumber mata pencaharian ialah dengan melaut. Nelayan yang tidak bisa melaut hanya dirumah saja, Kalau ada alat tangkap yang rusak, ya mereka memperbaikinya. Untuk memenuhi kebutuhan sehari-hari selama tidak turun ke laut, nelayan terpaksa meminjam uang kepada tauke tempat biasa mereka menjual hasil tangkapan. Bayarnya nanti setelah nelayan sudah bisa melaut dan mendapatkan hasil tangkapan yang memadai. warga juga mengharapkan pemerintah daerah setempat dapat mencarikan solusi untuk membantu nelayan saat tidak bisa melaut. Dalam penelitian ini mengunakan teori (Dunn, 2003) menggambarkan kriteria-kriteria evaluasi kebijakan untuk mengukur tingkat keberhasilan program bantuan untuk mengurangi hubungan patron klien Desa Malang Rapat sebagai berikut: 1. Efektivitas, 2. Efisiensi, 3. Kecukupan, 4. Perataan, 5. Responsivitas, 6. Ketepatan.

\section{METODE PENELITIAN}

Penelitian ini dilaksanakan pada Dinas Perikanan Kabupaten Bintan. penelitian yang digunakan adalah deskriptif dengan pendekataan kualitatif. Pendekatan kualitatif diguakan untuk mendapatkan data yang mendalam, suatu data yang mengandung makna. Makna adalah data yang sebenarnya, data yang pasti yang merupakan suatu nilai di balik data yang tampak (Sugiyono, 2016).

Penelitian deskriptif yaitu penelitian yang berusaha untuk menuturkan pemecahan masalah yang ada sekarang berdasarkan data-data, jadi ia juga menyajikan data, menganalisis dan menginterpretasi. Ia juga bisa bersifat komperatif dan korelatif. Penelitian deskriptif ini bertujuan untuk memecah masalah secara sistematis dan faktual mengenai fakta-fakta dan sifat-sifat populasi (Narbuko, 2015)

Penelitian ini bertujuan untuk menjabarkan fakta-fakta hasil penelitian secara mendalam dan terpusat berdasarkan data-data dan informasi yang diperoleh dari subjek penelitian dan dijabarkan secara deskriptif. Dalam penelitian, secara rinci akan dijelaskan tentang Evaluasi Strategi Pemeritah untuk mengatasi hubungan patron klien.

Sumber data yang menjadi bahan dalam penelitian ini adalah data primer, Data tersebut akan peneliti dapatkan dengan cara melakukan wawancara dengan beberapa subjek penelitian di Desa Malang Rapat Kecamatan Gunung Kijang Kabupaten Bintan. Dalam hal ini adalah wawancara yang dilakukan dengan informan seperti Kepala Dinas Perikanan Bintan, Kepala Desa, Ketua nelayan, Sekretaris Nelayan, dan Tauke-tauke yang ada di Desa Malang Rapat. data sekunder berupa catatan-catatan resmi, laporan-laporan, atau dokumendokumen serta data pendukung lainnya yang mendukung data primer terdapat di Dinas Perikanan Kabupaten Bintan, Kantor Desa Malang Rapat, dan juga Kepala kelompok Nelayan.

\section{HASIL DAN PEMBAHASAN}

Disini Persoalan utamanya nelayan tidak mampu mengimbangi kebutuhan modal yang mereka butuhkan dengan penghasilan yang mereka peroleh. Kebutuhan modal melaut relatif besar sedangkan keuntungan melaut relatif kecil, namun tauke dapat mengatasi persoalan 
tersebut. Keadaan nelayan seperti ini sangat menguntungkan tauke dengan bisnis perdagangan ikan yang dia miliki. Dalam permasalahan yang diharapkan pemerintah bantuan yang diberikan kepada nelayan bisa mengurangi ketergantuan nelayan dengan tauke. Dari pemasalah yang dialami masyarakat nelayan diDesa Malang Rapat, pemerintah mengeluarkan program bantuan yang mana agar bantuan yang diberikan oleh pemerintah bisa mengurangi hubungan pantron klien tersebut. Dalam hal ini pemerintah memberikan bantuan kepada nelayan dalam bentuk pompong, alat tangkap untuk mengatasi ketergantungan nelayan dengan tauke.

Patron klien adalah hubungan pertukaran hubungan antara kedua peran yang dapat dinyatakan sebagai kasus khusus dari ikatan yang melibatkan persahabatan instrumental dimana seorang individu dengan status sosio-ekonominya yang lebih tinggi (patron) menggunakan pengaruh dan sumber dayanya untuk menyediakan perlindungan, serta keuntungan-keuntungan bagi seseorang dengan status yang dianggapnya lebih rendah (klien). Penelitian ini membahas tentang hubungan Patron klien yang terjadi di Desa Malang Rapat yaitu hubungan nelayan dengan tauke, dimana tauke merupakan tempat bergantung para nelayan. sistem tauke dapat dinilai berdasarkan dampak positif dan negatif. (Dunn, 2003) menggambarkan kriteria-kriteria evaluasi kebijakan untuk mengukur tingkat keberhasilan suatu program sebagai berikut:

\section{Efektivitas Program}

Menurut (Dunn, 2003) menggambarkan kriteria-kriteria dalam evaluasi kebijakan untuk mengukur tingkat keberhasilan suatu program salah satunya adalah efektivitas. Efektivitas berasal dari kata efektif yang mengandung pengertian dicapainya keberhasilan dalam mencapai tujuan yang telah ditetapkan. Hal tersebut terkait antara hasil yang diharapkan dengan hasil yang sesungguhnya dicapai. Seperti yang dikemukakan oleh Arthur G. Gedeian dkk mendefinisikan efektivitas adalah That is, the greater the extent it which an organization's goals are met or surpassed, pesan-pesan untuk mempengaruhi. Berdasarkan definisi tersebut, peneliti beranggapan bahwa efektivitas bisa tercipta jika pesan yang disampaikan dapat mempengaruhi khalayak yang diterpanya. Efektivitas selalu terkait dengan hubungan antara hasil yang diharapkan dengan hasil yang sesungguhnya dicapai (Rahmadani, 2017). Sedangkan menurut Mahmudi dalam (Rahmadani, 2017) mengartikan bahwa efektivitas yang merupakan hubungan antara output dengan tujuan, semakin besar kontribusi (sumbangan) output terhadap pencapaian tujuan, maka semakin efektif organisasi, program atau kegiatan. Menurut teori Kebijakan Publik milik William N. Dunn kebijakan tersebut termasuk dalam tahap evaluasi kebijakan dengan model evaluasi retrospektif, Evaluasi ini hanya mendasarkan diri pada informasi yang telah ada tentang kebijakan yang sedang berjalan, yang berhubungan secara langsung dengan hasil output dan dampak kebijakan. yang menurut teori Dunn dalam (Adnin, 2017) bahwa model ini mengevaluasi dampak dari dilaksanakan kebijakan tersebut.

Berdasarkan hasil temuan yang didapat dari wawancara dan observasi bahwa program bantuan nelayan dalam bentuk bantuan alat tangkap dan pompong mengurangi ketergantungan nelayan terhadap tauke karena selama ini nelayan alat tangkap dan pompong yang dikuasai oleh tauke. Akan tetapi selama ini ketergantungan nelayan dengan tauke tidak hanya dua alat tersebut akan tetapi dalam bentuk modal untuk melaut. Rata-rata kebutuhan nelayan Rp.200.000 sekali melaut hal itu digunakan untuk minyak solar yang didapatkan dari hasil pinjaman dari tauke.

Bantuan yang diberikan oleh pemerintah agar bisa terwujudnya masyarakat nelayan yang berkualitas diharapkan dapat berdampak positif disegala sektor kehidupan masyarakat baik itu, ekonomi, sosial budaya, pertahanan dan keamanan dan lain sebagainya. Program bantuan memberikan manfaat besar bagi para nelayan tradisional, manfaat tersebut paling 
tidak untuk membantu mereka meningkatkan hasil tangkap, selain itu nelayan tradisional yang sebelumnya hanya bisa mencari ikan disekitar pantai, kini dapat melaut dengan jarak yang lebih luas karena memiliki kapal yang berukuran sedang. Manfaat yang dirasakan oleh nelayan adalah mereka dapat melimpat gandakan hasil tangkapan dari sebelum adanya bantuan, tidak hanya itu dengan peningkatan hasil tangkapan, kini nelayan tradisional dapat membantu keuangan keluarga guna keperluan hidup mereka. Disini Pemerintah sangat berperan penting dalam menentukan nasib para nelayan yang ada di Desa Malang Rapat untuk mensejahterakan hidup. Melalui bantuan yang diberikan pemerintah untuk masyarakat nelayan bisa dalam mengurangi ketergantuangan nelayan dengan tauke.

\section{Efisiensi Program}

Efektivitas dan efisiensi sangatlah berhubungan. Apabila kita berbicara tentang efisiensi bilamana kita membayangkan hal penggunaan sumber daya (resources) kita secara optimum untuk mencapai suatu tujuan tertentu. Maksudnya adalah efisiensi akan terjadi jika penggunaan sumber daya diberdayakan secara optimum sehingga suatu tujuan akan tercapai. Menurut (Dunn, 2003) menyebutkan bahwa efisiensi berkenaan dengan jumlah usaha yang diperlukan untuk menghasilkan tingkat efektivitas tertentu. Efisiensi yang merupakan sinonim dari rasionalitas ekonomi adalah hubungan antara efektivitas dan usaha, yang terakhir umumnya diukur dari ongkos moneter. Pendapat Zahnd dalam (Rahmadani, 2017) juga menyebutkan bahwa efisiensi berarti tepat atau sesuai untuk mengerjakan sesuatu dengan tidak membuang-buangwaktu, tenaga dan biaya. Berdasarkan beberapa pendapat di atas, maka efisiensi dapat diartikan sebagai suatu standar untuk menilai seberapa besar usaha yang dilakukan oleh pelaksana suatu kegiatan atau kebijakan dalam mencapai tujuan dan sasaran yang akan dicapai, Lukman dalam (Rahmadani, 2017).

Hasil temuan yang peneliti dapat mengenai efisiensi anggaran program bantuan dalam membantu masyarakat nelayan, pemerintah mempunyai hak untuk membuat kebijakan dan mengeluarkan kebijakan untuk membantu masyarakat nelayan yang ada di Desa Malang Rapat. Kemudian pemerintah memiliki anggaran dan berwewenang dalam memenuhi kebutuhan yang diperlukan oleh masyarakat yang sesuai dengan keahlian dan perkerjaan sebagai nelayan. Pemerintah mempunyai hak besar dalam mengeluarkan kebijakan dalam bentuk program bantuan yang mana tujuannya untuk mensejahterakan masyarakat nelayan. terwujudnya keberhasilan suatu program yang dikeluarkan, tentunya harus melibatkan berbagai pihak, dengan adanya kerjasama pemerintah. Hal ini dapat dilihat pemerintah saling koordinasi dengan UPTD Pelayanan Usaha Perikanan Kecamatan Gunung Kijang dan Teluk Sebong, sehingga bisa menilai sejauh mana keberhasilan program tersebut.

\section{Kecukupan Program}

Kecukupan dalam kebijakan publik dapat dikatakan tujuan yang telah dicapai sudah dirasakan mencukupi dalam berbagai hal. Menurut (Dunn, 2003) Kecukupan dalam kebijakan publik dapat dikatakan tujuan yang telah dicapai sudah dirasakan mencukupi berbagai hal. Kecukupan masih berhubungan dengan efektivitas, dengan mengukur atau memprediksi seberapa jauh alternatif yang ada dapat memuaskan kebutuhan, nilai atau kesempatan dalam menyelesaikan masalah yang terjadi. Sebelum suatu produk kebijakan disahkan dan dilaksanakan harus ada analisis kesesuaian metoda yang akan dilaksanakan dengan sasaran yang akan dicapai, apakah caranya sudah benar atau menyalahi aturan atau teknis pelaksanaannya yang benar. Dari pendapat tersebut dapat diketahui bahwa kecukupan memiliki hubungan dengan efektivitas yang memprediksi jauh tidaknya alternatif kebijakan yang ada, dapat memuaskan kebutuhan, nilai atau kesempatan dalam menyelesaikan masalah yang terjadi (Rahmadani, 2017). Yang dimaksud kecukupan adalah berkenaan 
dengan seberapa jauh suatu kebijakan tingkat efktifitasnya memuaskan kebutuhan nilai, atau kesempatan yang menimbulkan adanya masalah, Himawan dalam (Purnamasari, 2017). Dimana dalam suatu kebijakan terdapat alternatif apa yang akan dilakukan bila kebijakan telah diimplementasikan. Dengan kata lain seberapa jauh pencapaian hasil yang diinginkan telah memecahkan masalah. Indikator penilaiannya adalah pelaksana kebijakan sebuah kebijakan akan dapat berjalan dan mencapai tujuannya apabila di laksanakan dengan baik. Pelaksana kebijakan merupakan suatu unsur yang memiliki peran paling besar dalam pelaksanaan suatu kebijakan untuk mendorong pada tercapainya tujuan yang diinginkan.

Hasil temuan yang peneliti dapat yakni untuk melihat keberhasilan program bantuan. Dalam melihat kecukupan disini perlu adanya sebuah alternatif kebijakan demi menunjang kehidupan nelayan. Disini Pemerintah membuat kebijakan untuk membantu masyarakat miskin yang ada di pesisir pantai dalam memenuhi kebutuhan ekonomi. Dengan adanya bantuan sangat membantu masyarakat akan tetapi, kurangnya Sumber Daya Manusia (SDM) tentang apa yang di berikan membuat masyarakat tidak paham untuk mengunakannya. Seharusnya pemerintah harus membuat suatu pelatihan dalam mengunakan alat-alat yang di berikan. Dengan adanya pelatihan membuat masyarakat menjadi paham dalam mengunakan alat tangkap yang modern. Sering juga terjadi masyarakat menjualkan bantuan yang di berikan oleh pemerintah karena kurang kesadaran apa yang di bantu oleh pemerintah juga kurang pemahaman tentang teknologi canggih sehingga membuat masyarakat nelayan menjualnya. selanjutnya kecukupan mengenai permodalan nelayan salah satu program batuan dari pemerintah yaitu kredit usaha rakyat (KUR) bagi nelayan. Permasalah disini dari pihak bank tidak memberikan pinjaman penuh, karena itu dikhawatirkan akan menghambat dalam pembayaran angsurannya, kredit usaha rakyat (KUR) prosesnya lama, selain itu juga nelayan disana mayoritasnya nelayan kecil jadi sulit untuk melakukan pinjaman ke bank. Selajutnya dalam segi pemodalan, sebagian menggunakan modal dari tauke/juragannya. Sistem untuk modal dari tauke langsung ada pemotongan dari hasil tangkap pada hari itu juga,biasanya dari penangkapan dipotong 5\% untuk bagi hasil itu kesepakatan anatara nelayan dan tauke ada yang 50:50, dan ada juga 60:40. Sehingga memang kerugian menggunakan modal dari tauke, nelayan ini dipastikan banyak hutang, itu salah satu sebabnya kehidupannya nelayan terus akan miskin. Kemudian ada nelayan yang sudah bisa menggunakan bantuan yang diberikan pemerintah dan mempunyai modal sendiri, tetapi hasil melaut tersebut dijual kan dengan tauke disana, dikarena disana tidak ada TPI (tempat pelelangan ikan).

\section{Perataan Program}

Menurut (Dunn, 2003) Perataan dalam kebijakan publik dapat dikatakan mempunyai arti dengan keadilan yang diberikan dan diperoleh sasaran kebijakan publik. Kriteria kesamaan erat berhubungan dengan rasionalitas legal dan sosial dan menunjuk pada distribusi akibat dan usaha antara kelompok-kelompok yang berbeda dalam masyarakat. Kebijakan yang berorientasi pada perataan adalah kebijakan yang akibatnya atau usaha secara adil didistribusikan. Selanjutnya menurut Winarno (2002: 187) dalam (sari, 2019), Pemerataan dalam kebijakan publik dapat dikatakan mempunyai arti dengan keadilan yang diberikan dan diperoleh sasaran kebijakan publik Pelaksanaan kegiatan kebijakan harus bersifat merata dan adil bagi masyarakat yang menjadi kelompok sasaran yang mendapatkan pelayanan publik secara adil. Kebijakan yang berorientasi pada perataan adalah kebijakan yang akibatnya atau usaha secara adil didistribusikan. Suatu program tertentu mungkin dapat efektif, efisien, dan mencukupi apabila biaya dan manfaat merata. Kunci dari perataan yaitu keadilan atau kewajaran (Rahmadani, 2017). 
Hasil temuan yang peneliti dapat mengenai perataan penyaluran program bantuan yang disalurkan pemerintah yaitu dalam memberikan bantuan belum bisa dikatakan efektif, karena masih ada juga masyarakat nelayan yang belum menerima bantuan yang disalurkan pemerintah. Disini juga terjadi permasalahan dalam penyaluran bantuan itu, yakni bantuan yang diberikan pemerintah yang sudah mendapatkan bantuan itu, dapat lagi bantuan tersebut, sehingga terjadinya bantuan yang diberikan dijual oleh masyarakat nelayan itu, dan juga tidak meratanya bantuan yang disalurkan sehingga masih ada nelayan yang belum merasakan bantuan tersebut.

Kemudian dengan banyaknya manfaat yang didapatkan oleh masyarakat nelayan dari program-program bantuan yang disalurkan oleh pemerintah berjalan dengan baik walaupun masih banyak kekurangan dan belum semua nelayan merasakan tetapi sudah dilaksanakan dengan semestinya. Pemerintah membuat suatu program yang dimana, program ini ditunjukan kepada masyarakat yang layak menerima, Program yang dilakukan oleh pemerintah saat ini cukup baik, meskipun masih banyak terdapat beberapa nelayan yang masih kurang dalam respond menerapkan. Penyaluaran bantuan pun sangat perlu adanya pengawasan supaya tidak ada lagi masyarakat yang menjual bantuan yang diberikan. Agar apa yang diberikan bisa bermanfaat untuk nelayan dalam kehidupan kedepannya.

\section{Responsivitas Program}

Menurut William N. Dunn menyatakan bahwa responsivitas (responsiveness) berkenaan dengan seberapa jauh suatu kebijakan dapat memuaskan kebutuhan, preferensi, atau nilai kelompok-kelompok masyarakat tertentu. (Dunn, 2003) Responsivitas dalam kebijakan publik dapat diartikan sebagai respon dari suatu aktivitas, yaitu tanggapan sasaran kebijakan publik atas penerapan suatu kebijakan. Responsivitas (responsivennes) berkenaan dengan seberapa suatu kebijakan/program dapat memuaskan kebutuhan, prefensi atau nilai kelompok-kelompok masyarakat (Akbar, 2016). Keberhasilan kebijakan dapat dilihat melalui tanggapan masyarakat yang menanggapi pelaksanaan setelah terlebih dahulu memprediksi pengaruh yang akan terjadi jika suatu kebijakan akan dilaksanakan, juga tanggapan masyarakat setelah dampak kebijakan sudah mulai dapat dirasakan dalam bentuk yang positif berupa dukungan sedangkan penolakan adalah wujud negatifnya. Oleh karena itu, kriteria responsivitas cerminan nyata kebutuhan, preferensi dan nilai dari kelompokkelompok tertentu terhadap kriteria efektivitas, efisiensi, kecukupan, dan kesamaan. Dalam melaksanakan suatu kebijakan, keadilan harus menjadi dasar utamanya, dalam arti semua sektor serta semua lapisan masyarakat yang menjadi sasaran dan objek kebijakan harus sama-sama dapat merasakan hasil dari kebijakan tersebut (Rahmadani, 2017)

Hasil temuan yang peneliti dapat yakni bahwa respon masyarakat nelayan positif terhadap adanya program bantuan yang disalurkan oleh pemerintah. Masyarakat nelayan mendukung akan keberlangsungan program tersebut. Bantuan yang diberikan pemerintah, ada nelayan yang bisa menggunakan dan bisa mengurangi ketergatungan tersebut dan ada juga bantuan itu dijualkan dikarena kurangnya dalam pemberian pelatihan kepada nelayan sehingga nelayan tidak bisa menggunakan bantuan yang diberikan seperti kapal besar yang diberikan kenelayan kecil otomasi kapal tersebut tidak bisa digunakan. Selain itu diberikan kapal yang besar biaya operasionalnya untuk melaut lebih besar sehingga nelayan masih ke tauke untuk kebutuhannya melaut.

\section{Ketepatan Program}

Ketepatan adalah berkenaan dengan pertanyaan apakah kebijakan tersebut tepat untuk masyarakat. Apakah kebijakan yang telah diimplementasikan pemerintah antara tujuan dan hasil yang diperoleh, benar-benar bernilai/bermanfaat. Dengan kata lain apakah kebijakan 
yang ada benar-benar berguna atau bernilai. Untuk ketepatan alternatif yang digunakan dapat diukur dengan indikator: ketepatan dari produk kebijakan (Irawan, 2017). Menurut William N. Dunn dalam (Krisnia, 2017) menyatakan bahwa kelayakan (Appropriateness) adalah "Kriteria yang dipakai untuk menseleksi sejumlah alternatif untuk dijadikan rekomendasi dengan menilai apakah hasil dari alternatif yang direkomendasikan tersebut merupakan pilihan tujuan yang layak. Kriteria kelayakan dihubungkan dengan rasionalitas substantif, karena kriteria ini menyangkut substansi tujuan bukan cara atau instrumen untuk merealisasikan tujuan tersebut" Artinya ketepatan dapat diisi oleh indikator keberhasilan kebijakan lainnya (bila ada). Berdasarkan pendapat di atas, dapat diketahui bahwa ketepatan merupakan penilaian suatu tujuan dari sebuah kebijakan yang menjadi solusi dari masalah yang terjadi di tengah-tengah masyarakat sehingga bisa dilihat apakah dapat memecahkan masalah tersebut atau justru menimbulkan masalah yang lain (Rahmadani, 2017).

Hasil temuan yang diperoleh peneliti yakni program bantuan ini sudah tepat untuk dijalankan karena tujuan dari program ini sangat bernilai dan berguna untuk pengentasan kemiskinan bagi masyaralkat nelayan. Program ini mampu memberikan dampak yang signifikan terhadap pendapatan nelayan yang telah menggunakan bantuan yang diberikan oleh pemerintah dengan bijaksana. Dengan adanya bantuan tersebut maka pendapatan nelayan akan lebih meningkat daripada sebelum mendapatkan bantuan tersebut.

Selanjutnya dalam permasalahan modal pada musim peceklik mengakibatkan nelayan mengalami masa pengangguran yang beresiko terhadap kesejahteraan nelayan, jika nelayan tidak dapat bekerja maka untuk memenuhi kebutuhan hidupnya nelayan menggunakan tabungannya untuk digunakan. Ketika tabungan semakin berkurang, maka nelayan akan beralih pada bantuan orang lain dengan berhutang. Dalam hal ini nelayan membutuhkan modal yang dimilikinya untuk dapat digunakan secara maksimal dengan harapan dapat mempertahankan kebutuhan ekonomi keluarga. Modal memberikan harapan bagi masyarakat nelayan sebagai sumber daya yang bermanfaat dalam menghadapi perubahan iklim. Pada saat musim peceklik, nelayan lebih memilih untuk berhutang pada tauke. Pinjaman modal yang diberikan tauke membuka modal bagi nelayan untuk mengkases sumber daya yang dibutuhkan dalam menghadapi masa krisis ekonomi. Modal tidak hanya dibentuk melalui interaksi nelayan pada tauke, tetapi interaksi balik dari tauke membuat hubungan tersebut merupakan peluang bagi tauke.

Kemudian dengan permasalahan tersebut Koperasi yang dapat menjadi wadah untuk dapat menambah penghasilan keluarga nelayan agar hidup lebih baik dan sejahtera dalam masalah modal. Dalam koperasi perlunya Pengelolaan yang baik akan menjadikan koperasi tumbuh dan berkembang sehingga dapat meningkatkan kesejahteraan masyarakat nelayan. Masyarakat sejahtera ketika tersedia lapangan usaha yang akan menjadi sumber penghasilan masyarakat. Kemampuan akan membantu didalam mengembangkan usaha, untuk itu perlu diberikan pelatihan kepada masyarakat nelayan untuk dapat mengembangkan koperasi, agar kehidupan masyarakat nelayan lebih membaik.

\section{PENUTUP}

Kesimpulan dari evaluasi strategi pemerintah untuk mengatasi hubungan patron klien diDesa Malang Rapat sudah bisa dikatakan bisa mengurangi hubungan nelayan dengan tauke, didasarkan kriteria evaluasi. Pertama Efektivitas Program bantuan memberikan manfaat besar bagi para nelayan tradisional, manfaat tersebut paling tidak untuk membantu mereka meningkatkan hasil tangkap, selain itu nelayan tradisional yang sebelumnya hanya bisa mencari ikan disekitar pantai, kini dapat melaut dengan jarak yang lebih luas karena memiliki kapal yang berukuran sedang. Manfaat yang dirasakan oleh nelayan adalah mereka dapat melimpat gandakan hasil tangkapan dari sebelum adanya bantuan, tidak hanya itu dengan peningkatan hasil tangkapan, kini nelayan tradisional dapat membantu keuangan 
keluarga guna keperluan hidup mereka. Kedua, Efesiensi pemerintah memiliki anggaran dan berwewenang dalam memenuhi kebutuhan yang diperlukan oleh masyarakat yang sesuai dengan keahlian dan perkerjaan sebagai nelayan.

Pemerintah mempunyai hak besar dalam mengeluarkan kebijakan dalam bentuk program bantuan yang mana tujuannya untuk mensejahterakan masyarakat nelayan. terwujudnya keberhasilan suatu program yang dikeluarkan, tentunya harus melibatkan berbagai pihak, dengan adanya kerjasama pemerintah. Ketiga, Kecukupan Dengan adanya bantuan sangat membantu masyarakat akan tetapi, kurangnya Sumber Daya Manusia (SDM) tentang apa yang di berikan membuat masyarakat tidak paham untuk mengunakannya. Keempat, Perataan Program yang dilakukan oleh pemerintah saat ini cukup baik, meskipun masih banyak terdapat beberapa nelayan yang masih kurang dalam respond menerapkan. Penyaluaran bantuan pun sangat perlu adanya pengawasan supaya tidak ada lagi masyarakat yang menjual bantuan yang diberikan.

Agar apa yang diberikan bisa bermanfaat untuk nelayan dalam kehidupan kedepannya. Kelima, Responsifitas Respon masyarakat nelayan positif terhadap adanya program bantuan yang disalurkan oleh pemerintah. Masyarakat nelayan mendukung akan keberlangsungan program tersebut. Keenam,Ketepatan Program bantuan ini sudah tepat untuk dijalankan karena tujuan dari program ini sangat bernilai dan berguna untuk pengentasan kemiskinan bagi masyaralkat nelayan. Program ini mampu memberikan dampak yang signifikan terhadap pendapatan nelayan yang telah menggunakan bantuan yang diberikan oleh pemerintah dengan bijaksana. Dengan adanya bantuan tersebut maka pendapatan nelayan akan lebih meningkat daripada sebelum mendapatkan bantuan tersebut.

Sebaiknya Pemerintah dalam memberikan bantuan diharap adanya pengawasan dan konsultasi kepada masyarakat nelayan agar bantuan yang diberikan bisa tepat sasaran. diharuskan di Desa Malang Rapat membangun koperasi agar masyarakat nelayan bisa bertahan hidup pada musim tidak bisa melaut. Kemudian pemerintah saling berkerja sama dengan Ketua Nelayan, karena Ketua nelayan lebih tau masyarakat nelayan Desa Malang Rapat dan pemerintah mengadakan sosialisasi tentang bantuan yang akan diberi kemasyarakat nelayan.Sebaiknya di Desa Malang Rapat ada tempat pelelangan ikan, agar nelayan bisa menjual harga yang sesuai.

\section{Ucapan terimakasih}

Terimakasih atas Informan berdasarkan hasil wawancara pada penelitian ini adalah . Informan dari penelitian ini Dinas perikanan Kabupaten Bintan, kepala desa Malang Rapat, Ketua kelompok nelayan,sekretaris kelompok nelayan, masyarakat lokal/nelayan dan tauke. Sehingga memberikan informasi kepada peneliti untuk menyelesaikan penelitian ini.

\section{DAFTAR PUSTAKA}

\section{Sumber dari Buku dan Jurnal}

Dunn, William. N. (2003). Pengantar Analisis Kebijakan Publik. Yogyakarta: Gadjah Mada University Press.

Narbuko, Cholid dan Abu Achmadi. (2015). Metodelogi Penelitian. Jakarta: PT. Bumi Aksara.

Sugiyono. (2016). Metode Penelitian Kuantitatif, Kualitatif, dan R\&d. Bandung: Alfabeta.

Adnin Ridha Rerifki, Dody Setyawan, Asih Widi Lestari (2017). Evaluasi Kebijakan 
Rusunawa Dalam MengatasiPermukiman Kumuh Di Kota Malang. Jurnal Ilmu Sosial Ilmu Politik. ISSN 2442-6962. Vol 6. No.2.

Akbar, Muhammad, Firyal. (2016). Evaluasi Kebijakan Program Pemberian Dana Bantuan Operasional Sekolah. Jurnal Analisis Kebijakan dan Pelayanan Publik. pISSN: 24606162|eISSN:2527-6476 Vol 2. No.1.

Irawan, Rudy.(2017). Evaluasi program layanan rakyat untuk sertifikasi tanah (larasita) di kabupaten kampar.Jurnal Online Mahasiswa. ISSN: 2355-6919. Vol 4. No.2.

Marsha Krisnia, Lafitra. (2017). Studi Evaluasi Kebijakan Retribusi Parkir Berlangganan di Kabupaten Sidoarjo. Jurnal Kebijakan dan Manajemen Publik. ISSN 2303-3411. Vol 5. No.3.Hal 1-12

Purnamasari, Hanny, \& Ramdani, Rachmat. (2020). Evaluasi Program Badan Usaha Milik Desa (BUM DESA) Oleh Dinas Pemberdayaan Masyarakat dan Desa di Kabupaten Karawang. Jurnal Ilmu Pemerintahan. Vol 1. No.1.p-ISSN:2442-5958| e-ISSN: 25408674

Sari, Anis Gita. (2020). Evaluasi Program Keluarga Harapan Dalam Rangka Mengatasi Permasalahan Pendidikan Dan Kesehatan Di Kecamatan Semarang Utara Kota Semarang. Journal Of Public Policy and Management Review.Vol 9. No. 1

Sinaga, Herman. (2015). Pola Hubungan Patron- Klien Pada Komunitas Nelayan Di Kelurahan Malabro Kecamatan Teluk Segara Kota Bengkulu. Jurnal Agrisep. ISSN 1412-8837. Vol 15. No. 2. Hal 167-176.

Sufirudin. (2016). Hubungan Patron Klien Diantara Masyarakat Nelayan Di Desa Kangkunawe Kecamatan Maginti Kabupaten Muna Barat Provinsi Sulawesi Tenggara. Journal Of Social and Culture. Vol 9. No.17a

\section{Sumber Skripsi dan Internet:}

Rahmadani, Andi Nurul. (2017). Evaluasi Implementasi Perda No. 6 Tahun 2013 Tentang Pemenuhan Hak-Hak Kesehatan Bagi Penyandang Disabilitas Kusta Di Rsk. Dr. Tadjuddin Chalid Makassar. Administrasi dan kebijakan Kesehatan. Fakultas Kesehatan Masyarakat. Universitas Hasanuddin.

https://wartakepri.co.id/2019/07/26/bertemu-nelayan-malang-rapat-bintan-plt-gubernurisdianto-akan-bantu-48-ketinting/ (15 November 2019, pukul 14.23)

https://bintan.batampos.co.id/2019/08/03/nelayan-bintan-tak-bisa-melaut-ini-penyebabnya/ ( 23 November 2019, pukul 14.45 ) 